\title{
Impact of zinc on thyroid metabolism
}

\section{Introduction}

Thyroid gland is the most important endocrine gland in human body which performs various functions. Thyroid hormones such as thyroxin and triiodothyronine are essential various metabolic functions and also required for normal functions of body tissues. These thyroid hormones affect metabolic rate and consumption on oxygen. ${ }^{1}$ The most important constituent of thyroid hormones is iodine. The geographical areas where the amount of iodine is less thyroid dysfunction and diseases are very common. Thyroid disease is the commonest endocrine disorder in the whole world. Thyroid diseases are caused due to over secretion and under secretion of thyroid hormones. These diseases are more common in females. ${ }^{2,3}$ Zinc is essential trace element for human body in limited amount. It is essential for normal functioning of metabolic homeostasis, immune system, cell stimulation, enzyme activity, protection against oxidative stress, and neural transmission. ${ }^{4,5}$ It works as co-enzyme factor for many enzymes which are involved in various metabolic processes and it is essential for sensitizing the tissues to thyroid hormone. ${ }^{6}$ Zinc is also involved in cell differentiation, proliferation, cell repairing and renewal. The importance of zinc in endocrine system is that it effect on growth, endocrine homeostasis, and thyroid function and on glucose metabolism. ${ }^{7}$ Deficiency of zinc in the body may result in decreased levels of secretion of thyroid hormones which affects the normal metabolism of the body and resting metabolic rate. Some of the studies shown that deficiency of zinc is associated with enhanced the expression of hepatic thyroxine-5'-monodeiodinase enzyme activity which catalyses the thyroid hormone inactivation. ${ }^{8,9}$

\section{Hypothyroidism and zinc}

Zinc is essential trace element for normal levels of thyroid hormones such as triiodothyronine (T3), tetraiodothyronine (T4), and thyroid stimulating hormone (TSH) (Table 1). Some of the studies showed that zinc deficiency leads decrease in T3 level. The well known effect of zinc on some endocrine glands such as pituitary- a master gland and on hypothalamus is that it appears a role in the synthesis of releasing hormone such as thyrotrophic releasing hormone (TRH). Some of the studies showed that in hypothyroidism alteration in zinc level. Patients with thyroid cancer have significantly low level s of zinc. ${ }^{10-12}$ In Hypothyroidism metabolic rate gets reduce which results in adverse effect on organ system (Table 2).$^{13}$ Hypothyroidism can lead to number of complications in humans such as:

a) Mental health issues such as depression and also cause the slow functioning of brain.

b) Heart problems because of increase in the level of Low density lipoprotein (LDL) cholesterol. Sometimes it causes heart failure and enlarges heart.

c) In hypothyroidism the low levels of thyroid hormone can alter the process of ovulation which leads to infertility in women.

\section{Hyperthyroidism and zinc}

Consumption of high amount of zinc can contribute to
Volume 5 Issue I - 2018

\author{
Sabina Khanam \\ Department of Biological Sciences, Yobe State University, Nigeria
}

Correspondence: Sabina Khanam, Department of Biological Sciences, Yobe State University, Damaturu, Nigeria, Email sabinakhanam@ymail.com

Received: October 22, 2017 | Published: February 26, 2018

hyperthyroidism or Graves' disease because zinc acts as a stimulator to the thyroid gland. Patients suffering from hyperthyroidism have higher amount of urinary excretion of zinc. ${ }^{14}$ Over activity of thyroid gland or some other causes leads to hyperthyroidism (Table 3). When tissues are exposed to higher concentrations of thyroid hormones then some physiological, clinical and biochemical alterations occur in the body (Table 4). Many studies shown that hyperthyroidism affects many organ systems. ${ }^{15}$ Some of the researchers reported that zinc is a fundamental component of enzymatic antioxidant system with several antioxidant properties. Zinc is required in the body for optimal activity of many hormones like thyroid hormone. ${ }^{16,17}$

Table I Causes of Hypothyroidism

$\begin{array}{ll}\text { Autoimmune disease } & \text { Radiation Therapy } \\ \text { Thyroid surgery } & \text { Treatment for hyperthyroidism } \\ \text { Medications } & \text { Pregnancy } \\ \text { lodine deficiency } & \text { Pituitary disorder } \\ \text { Congenital disorder } & \end{array}$

Table 2 Symptoms of Hypothyroidism

$\begin{array}{ll}\begin{array}{l}\text { Elevated blood cholesterol } \\ \text { level }\end{array} & \begin{array}{l}\text { Muscle weakness, Muscle aches } \\ \text { and stiffness }\end{array} \\ \text { Slowed heart rate } & \text { Depression } \\ \text { Excessive sleepiness } & \text { Constipation } \\ \text { Irregular menstrual periods } & \text { Weight gain } \\ \text { Thinning of hair } & \text { Dry skin and puffy face }\end{array}$

Table 3 Causes of Hyperthyroidism

Excessive intake of iodine $\begin{aligned} & \text { Hyperfunctioining of thyroid } \\ & \text { nodules }\end{aligned}$

Thyroid cancer

Alteration in the secretion of TSH

Inflammation in the thyroid gland

Grave's disease

Postpartum thyroiditis Toxic thyroid adenoma 
Table 4 Symptoms of Hyperthyroidism

\begin{tabular}{ll}
\hline Fast and Irregular heartbeat & Vomiting, Nausea \\
Difficulty in sleeping & Weight loss \\
Increased appetite & Dizziness and shortness of breath \\
Brittle hair and hair loss & Development of breast in men \\
Congestive heart failure & Protruding eyes \\
Fertility problems & Paralysis \\
Increased sweating & Light menstrual periods \\
\hline
\end{tabular}

\section{Acknowledgment}

None.

\section{Conflict of interest}

None.

\section{References}

I. Kologlu S, Erdogan G. Thyroid: general remark and information. In: Erdogan G, editor. Kologlu Endocrinology. Basis and Clinic. 2nd ed. Ankara: Nobel Bookstore; 2005:I55-72.

2. Fabrizio M. Classification of thyroid diseases: suggestions for a revision.J Clin Endocrinol Metab. 2003;88(4): I 428- 4332.

3. Garber JR, Cobin RH, Gharib H, et al. Clinical practice guidelines for hypothyroidism in adults: cosponsored by the American Association of Clinical Endocrinologists and the American Thyroid Association. Endocr Pract. 20I2; I8(6):988-1028.

4. Rundles-Cunningham S. Zinc modulation of immune function: Specificity and mechanism of action.J Lab Clin Med. 1996; I28(I):9-II.

5. King JC, Cousins RJ. Zinc. In: Shils ME, Shike M, Ross AC, Caballero B, Cousins RJ, editors. Modern nutrition in health and disease. Philadelphia: Lippincott Williams and Wilkins, 2006; 27I-285.
6. Kaya S, Kececi T, Halilo S. Effect of zinc and vitamin supplements on plasma level of thyroid hormone, cholesterol, glucose and egg yolk cholesterol of laying hens. Res Vet Sci. 200 I;7 I (2): I35-I 39.

7. MaretW. Zinc in Human Disease. Met lons Life Sci. 20I3; I3:389-4I4.

8. El-sisy GA, Abdel-Razek AM, Younis AA, et al. Effects of dietary zinc or selenium supplementation on some reproductive hormone levels in male Baladi Goats. Global Veternaria. 2008;2:46-50.

9. Oliver JW, Sachan DS, Su P, et al. Effects of zinc deficiency on thyroid function. Drug-Nutrient Interactions. 1987;5(2): I I 3-I 24.

10. Brandao Neto J, Saturnino A, Leite LD De, et al. Lack of acute zinc effect on thyrotropin releasing hormone-stimulated thyroid-stimulating hormone secretion during oral zinc tolerance test in healthy men. Nutr Res; 2006;26(10):493-496.

II. Majewask U, Braziewicz J, Banas D, et al. Zinc concentration in thyroid tissue and whole blood of women with different diseases of thyroid. Biol Trace Elem Res. 2001;80:193-199.

12. Kucharzewski M, Braziewich J, Majewska U, et al. Copper, zinc, and selenium in whole blood and thyroid tissue of people with various thyroid diseases. Biol Trace Elem Res. 2003;93(I-3):9-I8.

13. Golden SH, Robinson KA, Saldanha I, et al. Clinical review: prevalence and incidence of endocrine and metabolic disorders in the United States: a comprehensive review.J Clin Endocrinol Metab. 2009;94(6): I853-I878.

14. Aihara K, Nishi Y, Hatano S, et al. Zinc, copper, manganese, and selenium metabolism in thyroid disease. American Journal of Clinical Nutrition. 1984;40(I):26-35.

15. Ludgate M, Crips M, Lance C, et al.The thyrotropin receptor in thyroid eye disease. Thyroid. 1998;8(5):4 I I-423.

16. Formigari A, Irato P, Santon A. Zinc, antioxidant systems and metallothionein in metal mediated-apoptosis: biochemical and cytochemical aspects. Comp Biochem Physiol C Toxicol Pharmacol. 2007; I 46(4):443-459.

17. Catania AS, Barros CR, Ferreira SR. Vitamins and minerals with antioxidant properties and cardio metabolic risk; controversies and perspectives. Endocrinol Metabol. 2009;53(5):550-559. 